\title{
Black College Athletes' Perceptions of Academic Success and the Role of Social Support
}

\author{
Akilah Carter-Francique \\ Texas A\&M University \\ Algerian Hart \\ Western Illinois University \\ Astin Steward \\ Texas A\&M University
}

\begin{abstract}
The purpose of this study is to understand Black college athletes' perceptions of academic success and how social support contributes to their academic success at predominantly white institution of higher education (PWIHE). Utilizing a qualitative approach, the authors conducted narrative interviews to capture the experiences of Black college athletes $(n=9)$ at a PWIHE in the southwest region of the United States. Critical race theory was employed to understand the social realities and academic experiences of racial minorities within the academic environment. Findings revealed Black college athletes' social support was based on their role as a college athlete and as a racial minority, thus reinforcing the notion of social isolation and alienation. Acknowledging the National Collegiate Athletic Association's (NCAA) definition of academic success (e.g., grade point average, graduation), it is plausible that understanding how college athletes perceive academic success and value of social support can aid in achieving academic success according to the NCAA of not only Black college athletes, but a diverse body of college athletes.
\end{abstract}

Keywords: college athletes, Black/African American, academic success, social support

The purpose of this study is to understand Black college athletes' perceptions of academic success and how social support contributes to their academic success at predominantly White institution of higher education (PWIHE). According to the National Collegiate Athletic Association (NCAA), academic success for college

Carter-Francique and Steward are with the Dept. of Health and Kinesiology, Texas A\&M University, College Station, TX. Hart is with the Department of Kinesiology, Western Illinois University, Macomb, Illinois. 
athletes is equated to maintaining eligibility. For Division I athletes, this includes "progress-toward-degree" policies which necessitate college athletes advance toward graduation annually (National Collegiate Athletic Association [NCAA], 2012). College athletes must demonstrate academic progress by completing a percentage of their required coursework (e.g., $40 \%$ at the end of second year, $60 \%$ at end of third year, $80 \%$ at end of the fourth year) (NCAA, 2011b). In addition, college athletes have to earn six credit hours each semester and meet the minimum institutional required grade point average. Thus, the definition of academic success for this study is based on the NCAA's policies that include: (a) passing academic courses to demonstrate progress toward graduation, (b) meeting the required grade point average, and (c) graduation (NCAA, 2011b).

Providing a working definition of academic success is significant when discerning college athletes' perceptions of academic success. Academic success can be measured based on cognitive variables (e.g., grade point average, test scores) and noncognitive variables (e.g., positive self-concept, leadership, understanding racism; Tracey \& Sedlacek, 1987) and thus interpretation is based on a person's perspective and preference (Sedlacek \& Adams-Gaston, 1992). Within the NCAA, and among concerned stakeholders (i.e., boosters, faculty, athletic administrators, college athletes), the notion of academic success and the education of college athletes has been a foundational point of debate and has undergone decades of reform to determine the appropriate measures of success (see Anderson \& South, 2007; Davis, 2007; Oriard, 2012).

In 2011, the NCAA hosted a Scholarly Colloquium focusing on the state of college athletics with regard to academic reform. Oriard (2012) explicated that the history, context, and changes on academic reform means "thinking primarily about football and men's basketball, but that does not exclude thinking about how a single set of standards or requirements serves or does not serve the interests and needs of all athletes in all sports" (p. 4). In other words, the former and current academic policies were intended for the success of Division I men's football and men's basketball athletes. The primary participants in men's football and men's basketball are Blacks (football 45.8\%; men's basketball 60.9\%; Lapchick, Hoff, \& Kaiser, 2011), a population with a history of academic challenges. Black college athletes' academic challenges have, thus, been an issue of contention since integration, as race and racism have been at the fore of their educational and college experiences (see Anderson \& South, 2007; Davis, 2007; Donnor, 2005; Edwards, 1984, 1985; Hawkins, 2001, 2010; Hodge, Harrison, Burden, \& Dixson, 2008; Purdy, Eitzen, \& Hufnagel, 1982; Singer, 2009). Black college athletes' sociocultural and psychosocial transitions from high school to college demark one of the first challenges during their educational and athletic journey in the PWIHE.

Arguably, the transition from high school to college may be difficult for students in general, but the unique responsibilities, expectations, and experiences that come with being a NCAA Division I college athlete compound and impact college athletes academic experiences (Parham, 1993). Not only is the academic transition between high school and college complicated to negotiate, but the change in social surroundings that come with moving away from home may also impact the experiences of college athletes at PWIHEs, especially those who are racial minorities (Hawkins, 2010). This issue of transition is especially salient for Black college athletes, as many come from predominately Black neighborhoods, and are 
suddenly in a predominately White setting at PWIHE's (Carter \& Hawkins, 2011; Hawkins, 2010; Singer, 2005b).

Regardless of sport, college athletes spend a large portion of time practicing, recovering, traveling, and competing in their respective sport. These highly regimented schedules are organized in such a manner that college athletes find themselves isolated from the general student body population, and immersed in a sport culture which highly focuses on athletic performance, rather than academic performance (Gaston-Gayles, 2004). Steele, Spencer, and Aronson (2002) further illuminated this point by highlighting how the internalized beliefs one holds about the self may negatively impact beliefs about one's own academic potential and effectively decrease performance in those areas. Identified as stereotype threat (Steele \& Aronson, 1995; Steele, Spencer, \& Aronson, 2002), the internalized negative beliefs, or negative stereotypes, affect members of under-represented groups in a variety of contexts based on the social realities within those contexts. Hence, the social reality as athlete in conjunction with the social constructions of race (e.g., racism) and class (e.g., classism) in a PWIHE context can cultivate an environment of intellectual inferiority and the "dumb jock" mentality (Edwards, 1984; Sailes, 1993, 1998).

Interestingly, some researchers believe that contact with those outside of sport may benefit college athletes and help decrease the effects of the "dumb jock" mentality (Comeaux \& Harrison, 2011; Hodge et al., 2008). Comeaux and Harrison noted that the missing relationship with the general population may have a deleterious effect on college athletes, as a relationship with students outside of athletics may impact goals and activities in a positive manner, giving college athletes an opportunity to strengthen their other (nonathlete) identities. Besides more interaction with noncollege athletes, Comeaux and Harrison $(2007,2011)$ have posited that by strengthening other identities and empowering college athletes, a positive change could be realized. To counteract the singular minded athlete identity, some scholars have sought to emphasize the academic identity with the creation of the "Scholar Baller" paradigm. The idea of the "Scholar Baller" lends itself to using the same competitive nature that many athletes exude in their sport and transferring it to the academic setting, thus helping athletes to truly engage the academic setting (Comeaux \& Harrison, 2007, 2011; Gaston-Gayles, 2004). The "Scholar Baller" paradigm is also strengthened by the motivation based academic success literature (see Gaston-Gayles, 2004), which demonstrates how students who are motivated academically perform better than those who are not. Yet, in order for the "Scholar Baller" paradigm to work, college athletes must form relationships and maintain adequate positive social support, which is oftentimes absent or lacking.

\section{Social Support}

Understanding the definitions and aiding benefits of social support is pertinent, especially as it relates to the transitional experiences of college students. The concept of social support is rooted in the field of health sciences (Cobb, 1976; House, Landis, \& Umberson, 1988) and is a topic of interest in the field of psychology (Cohen, 1986; Procidano \& Heller, 1983; Sarason, Levine, Basham, \& Sarason, 1983; Thoits, 1986; Vaux, 1988) and sociology (House, 1987). Therefore, it is important to clarify (a) the definition of social support and (b) the ways in which social 
support contributes to the academic success, as well as, academic persistence, and the sociocultural and psychosocial challenges of Black college athletes at PWIHEs.

Cobb (1976) describes social support from a psychological perspective as "information leading the subject to believe that he (sic) is cared for and loved, esteemed, and a member of a network of mutual obligations" (p. 300). According to Sarason and colleagues' (1983) sociological perspective, social support is described as "the existence or availability of people on whom we can rely, people who let us know that they care about, value, and love us" (p. 127). Thoits (1986) describes social support as "coping assistance, or the active participation of significant others in an individual's stress management efforts" (p. 417). Thus, social support serves as an important element in allowing people to cope with stress and/ or stressful life events.

Social support provides feedback and/or assistance that involve a level of mutual trust between the individual and her or his networks of support(s). Thoits' (1995) examined the relationship among stress, coping, and social support and found that three concepts (e.g., social integration, emotions, confidant relationship) are linked to one's physical and mental health. In particular, Thoits found (a) social integration is related to physical and mental health, but does not protect against chronic stressors; (b) emotional social support perceptions are related to increased physical and mental health and can protect against chronic stressors; and, (c) the greatest measure of support is a personal confidant, or maintaining a confiding relationship, as this reduces the physical and mental impact of the stressor. Thus, the promotion of coping strategies and/or social support structures will have a positive influence on the psychological well-being of an individual.

Coping has been explored in athletics, but the focus has mainly been on athletic performance and competition (Anshel, 2001; Anshel, Sutarso, \& Jubenville, 2009) and, as a result, there is little work exploring the experiences of athletes beyond the field and courts of play (Carter \& Hawkins, 2011). Carter and Hawkins (2011) examined the coping experiences of college athletes beyond the field and court of play. More specifically, the authors examined Black female collegiate athletes and their coping styles and strategies. They found Black female athletes were faced with the stress of alienation and isolation based on her racial and athletic status. Based on this chronic stress, the Black female college athletes adopted an avoidance coping style for which the authors suggested a need for safe spaces and support systems, thereby affording this populous successful matriculation in collegiate environment.

As alluded, transitioning from one environment to another (e.g., high school to college) can be viewed as a stressful life event, and, according to Evans, Forney, and Guido-DiBrito (1998) social support is one way to aid a student's ability to cope with their transition into a new environment. Schlossberg, Waters, and Goodman (1995) present transition as "any event, or non-event, that results in changed relationships, routines, assumptions, and roles" (p. 27). Thus, the developmental challenges and experiences of college students (see Evans et al., 1998; Pascarella \& Terenzini, 1998, 2005) warrant a greater understanding of how social support aids in their academic success.

House's (1981) sociological research on social support delineates the specific ways in which the types and measured facets provide aid or function to the individual. House (1981) presents four categorical functions of social support: (a) appraisal support, (b) emotional support, (c) informational support, and d) instrumental 
support. Appraisal support is described as an individual or organization providing information, constructive criticism, and/or affirmation that is beneficial for oneself. Emotional support is described as providing a nurturing environment in which trust, love, and/or care is provided. Informational support is described as an individual or organization providing information, advice, or suggestions. Instrumental support is described as an individual or organization providing tangible services and/ or assistance that are beneficial to oneself. While each of these functional supports can be deemed as separate entities, each are just as likely to serve as overlapping supports (House, 1981), which can make it difficult to discern which function the social support is providing at a specific moment.

\section{Critical Race Theory}

Exploring the educational experiences of Black students in a PWIHE warrants a critical perspective of their experiences. As presented, race and racism have marginalized their educational experiences and created a gap in their academic achievement when compared with whites. More specifically, Ladson-Billings (1998) suggests that "there was a move toward affirmative action and the creation of African Americans and other marginalized groups as 'protected classes' to insure that they were not systematically screened out of opportunities in employment, [and] college admission ..." (p. 18). But despite the legislative policies and educational progress, "...educational researchers, practitioners, and students are still in need of a language that will provide the necessary tools for effectively analyzing and coming to terms with the impact of race and racism on education" (Lynn, Yosso, Solórzano, \& Parker, 2002, p. 3). Therefore, employing critical race theory to address the educational terrain and experiences of Blacks has proven successful and useful (Lynn et al., 2002).

Critical race theory (CRT) elucidates inequities within the educational environment while simultaneously attempting to transform educational policies (Delgado, 1995; Delgado \& Stefancic, 2001). More specifically, CRT centers race and racism at the fore of discussions with marginalized groups to (a) understand its role in educational and social institutions and (b) aid in the elimination of oppressive practices such as racism, sexism, and classism (Bell, 1980; Delgado, 1989; Solórzano \& Yosso, 2002). A derivative of critical legal studies (see Tate, 1997), CRT utilizes several tenets to explicate the oppressive social realities which include, but are not limited to: (a) the intercentricity of race and racism with other forms of subordination; (b) the challenge to dominant ideology; (c) commitment to social justice; (d) the centrality of experiential knowledge; and (e) the transdiciplinary perspective (Solórzano \& Yosso, 2002; Yosso, 2005).

As stated, these tenets are used to elucidate the role race and racism play within the context of educational institutions. In regards to sport, CRT is a burgeoning theoretical framework (Hylton, 2005; Singer, 2005a) which has been helpful in: (a) illuminating the racialized experiences of Black male college athletes (Donnor, 2005; Singer, 2005b), (b) understanding Black female student-athlete identity negotiation (Carter, 2008), and c) recognizing the relevance of mentoring for Black female student-athletes (Carter \& Hart, 2010). Thus, CRT is a viable framework for understanding this marginalized population in society, sport, and institutions of higher education. 


\section{Method}

\section{Participants}

The participants in this research examination were Black women $(n=7)$ and men $(n=2)$ participating in intercollegiate athletics at a PWIHE in the Southwest United States. They participated in a variety of sports, including football $(n=2)$, women's basketball $(n=2)$, women's soccer $(n=1)$, and women's track and field $(n=4)$. The academic majors represented included Agricultural Leadership $(n=$ $3)$, Biomedical Science $(n=1)$, General Studies $(n=2)$, Marketing $(n=2)$, and Sociology $(n=1)$. The self-reported grade point averages ranged from 2.0 to 3.0 on a 4.0 scale with a mean of $2.45(S D=.487)$.

\section{Procedure}

The research was guided by an exploratory design to better understand the topic of this study. This approach has some limitations as researched participants: (a) rarely provide satisfactory answers to researched questions and (b) are not representative of the overall population (Babbie, 2001). Acquiring access to conduct research with collegiate athletes is a complex process. However, the primary researcher was able to establish rapport with key administrators, staff, and coaches within the athletic department. These relationships were helpful in initial access; however, willing college athlete participation remained a dominant challenge to the research participation.

Based on the research design and its limitations, snowball sampling was used to select the participants for this study. According to Hutchinson (2004), snowball sampling is beneficial when the targeted population is "unavailable or when access to population members is restricted" (p. 292), such as college athletes. The goal is to obtain participants by way of referral, and thus identify others from that population.

We made initial contact by visiting the athletic academic center for one week during the evening study hall hours. The first author served as a program codirector for one of the athletic department's student support programs at the researched site. Thus, some of the participants $(n=4)$ were familiar with the primary researcher as the codirector of the support program, but did not necessarily participate in the support program. The goal was to obtain participants from revenue (i.e., basketball, football) and nonrevenue sports (i.e., soccer, tennis, track and field). As such, the goal was to understand Black college athlete experiences, their perceptions of social support, and how their experiences and perceptions relate to their academic success. Nine college athletes agreed and consented to participate in the forty-five minute, semistructured qualitative interviews.

\section{Interview Guide}

The instrument used to collect the data was one 10-minute demographic questionnaire and one forty-five minute audiotaped semistructured interview. The demographic questionnaire consisted of athletic information (e.g., athletic team membership, athletic classification, scholarship status), campus life information (e.g., live on or off campus, have a full or part time job, extracurricular activity or organizational membership), and personal demographic information. The narrative 
interviews consisted of three sections to understand the Black college athlete experiences and how race and social support impacted their academic experiences within the PWIHE. The first section was designed to understand the personal and high school experiences (e.g., "were there any person or persons who assisted/ mentored you through high school"); the second section designed to understand their collegiate experience (e.g., "how would you define the term academic success"); and the third section was designed to understand their social support in the collegiate environment (e.g., ("explain how your social networks have provided social support and contributed to your academic successes").

\section{Data Analysis}

The nine qualitative interviews were transcribed verbatim. The participants were given the opportunity to review the transcription, or member check the interview (Lincoln \& Guba, 1985); however, none of the participants desired to review the transcripts. Following this, and to avoid researcher biases, the data were independently analyzed, categorized, and coded into themes according to Strauss' guidelines for inductive-deductive content analysis. Utilizing inductive analysis allowed the researchers to immerse in the nine transcripts to determine themes, which were relevant and significant. While, deductive analysis allowed the researchers to determine the categorical areas with regard to CRT. Therefore, utilizing inductive and deductive content analysis in tandem rooted the experiences and voices of the participants in the theoretical framework (Denzin, 1978; Glaser \& Strauss, 1967).

\section{Findings}

The purpose of this examination is to understand Black college athletes' perceptions of academic success and how social supports contribute to their academic success within the context of PWIHE. The nine Black college athletes articulated their perception on the following areas of interests: (a) definition of academic success and (b) how support networks provided social support for their academic successes. Thus, we focus our discussion on these two broad themes.

\section{Defining Academic Success}

In an effort to establish an understanding of how the Black college athletes' social networks provide social support, it was important to acknowledge their definitions of academic success. The nine Black college athletes provided a mix of cognitive and noncognitive definitions for academic success. The cognitive definitions included the referenced theme of "grades" and "graduation." For example, two participants explained that grades were the definition of academic success. One student felt that when they made a certain grade, it demonstrated personal academic success. Another participant indicated making grades traditionally understood as 'good' provided a marker of success. The student noted: "Um, I think when I make Cs, to be a C average student is something, that I work for." Only one participant pointed to graduation as an indicator of success.

The noncognitive definitions included three themes: "personal efforts and balance the college athlete role," "retaining information and applicability to life," and 
"networking." Four participants stated academic success was based on personal effort and balancing the student-athlete life role. More specifically, two participants explained that their personal effort was based on achieving what they knew they are capable of attaining. For example, one participant suggested "performing better than you did in high school" as an academically successful effort. Two other participants explained academic success is determined by a person's ability to balance their responsibilities as a student and an athlete. The following quotes illustrate these perspectives:

- I'd say, that you're academically successful, not maybe if you're making all A's and stuff, but if you're putting forth the most effort in doing like what you are capable of doing.

- I feel like if you did better than you did in high school. If you, you know, if you walk away with some knowledge, you've become an academic success, I don't think it means you have a 4.0.

- I think that academic success is like, being able to like balance all of the many things that you have to do ...

- Um, academic success, I guess succeeding in the area that like, academically, not only to better yourself and the career you pursue but also being able to compete in your sport. .

In addition to these perspectives, one participant explained academic success was based on a person's ability to retain information and how that information could be applicable to life after college athletics. The participant understood grades were an indicator of being academically successful but also understood that knowledge is not solely based on objective, or cognitive, measures. The participant noted: "Um, I think academic success is about like retaining the information that you learned, like sometimes it's not always about what kind of grades you make because sometimes everybody is not the best test taker in the world but I think like if you can learn something from school and apply it to your life or your job or whatever then I feel like that's successful."

Finally, another participant explained that the ability to network was academic success. While the athlete also acknowledged cognitive measures of academic success, she believed that meeting influential people played a significant role and served as motivation to be academically successful. This was captured in the following dialogue: 'Um, I'm a firm believer in it's not what you know it's who you know. So, I think, um, putting yourself into a position to get into the place that you want to be, um, has a lot to do with your academic success."

Thus, the nine Black college athletes shared their perceptions of academic success. Again, the NCAA's definitions of academic success reflect cognitive variables as measures of success (NCAA, 2011b, 2012). Subsequently, two participants presented cognitive variables as definitions for measures of academic success. Conversely, seven participants presented noncognitive variables as definitions for measures of academic success.

\section{Effects of Support Networks}

It was important to understand the nine Black college athletes' definitions of academic success. Acknowledging their definitions of academic success provided 
insight on the ways in which their identified social networks provided social support and ultimately how the social support contributed to their "academic successes." The nine Black college athletes identified a range of groups and individuals in their social networks whom provided social support to include persons' on-campus and off-campus. The on-campus supports consisted of athletics academic support, athletic team, academic faculty and staff, and nonathlete friends. The off-campus supports consisted of family, athletic team, nonathlete friends, and religion. Based on the two different support network communities, the Black college athletes discussed the ways in which these persons contributed to their academic experiences and successes. These came in the areas of "rules, guidance, and responsibility," "tutoring," "access to services and networks," and "unconditional support."

The participants noted their support networks provided "rules, guidance, and responsibility." The participants acknowledged the role of the academic staff for the athletic department. These persons provided direction and guidance when selecting courses and completing academic tasks. Therefore, in the academic staffs' administration, they had to enact parameters and rules (e.g., study hours) so they can achieve academic success. For instance, one athlete commented, "I feel like Sam [athletic academic adviser] had helped me the most academically just by being there and telling me things that I should do and what I need to do, he always tries to help basically." Another participant also noted the importance of athletic department support personnel, noting:

Yeah I think that they [athletic academic support staff] have done all that they can do to help me .. . I think that its good, like I said, that they have hours in place for people to, you know, definitely have to be at study hall and having the coaches enforce that I think is a good thing to let people know that they can't just come here and you know not worry about school and just focus on sports, but they're expecting them to make the grades, and you know you have to, to remain eligible.

In addition, for some of the participants they recognized that while they received rules and guidance from these persons, they also had to take responsibility for their academics. Reflective of this, one participant noted, "they [athletic academic staff] definitely did they part. I just have to do more of my own part and really focus on what I need to get done. They going to put me in the right direction I just gotta get there and get it done myself.

Two of the participants stated how "tutoring" contributed to their academic success. One participant's reflected how the tutors, provided through their academic staff for the athletic department, facilitated in the completion of class assignments: "they [athletic academic support staff] helped me with many of my school projects." Not all of the assistance came from paid athletic department personnel, though. One participant spoke of how a teammate served as a peer tutor for one of her academic courses: "uh, actually one of the girls on my team, when I had trouble in physics she [teammate] actually tutored me, and tried to help me out."

Support networks also provided participants with access to "services and networks." One participant spoke of how the Life Skills Coordinator was instrumental in addressing her transition from being a college student to achieving employment in her career of choice through resume writing and career fair networks. She noted: "The Life Skills Coordinator even helps us find a job and write a resume. She helps 
us with networking and building those connections to help get a job. Also, there is a ton of career fairs on campus that also helps to make sure that the day after you graduate you have a job." Another participant shared how their social networks of faculty, athletic staff, and peers helped to establish contact with others who assist their lives. That athlete commented: "Well they're [professors, coaches, friends] always there and if you have a problem they are willing to help you find someone to do better in a certain area."

Finally, some participants did not identify a specific way in which their support networks provided social support for their academic successes, but instead offered responses that reflected "unconditional support." Unconditional support for these students included their teammates and the athletic department's academic advisers and tutors each serving as "confidants" such that the students received personalized benefit. Thus, while their support networks provided academic support, they also provided supporting services based on the respective requests of the participants. Reflective of these sentiments, one participant noted: "Yes definitely, the people at (the Academic Center) [athletic academic support staff] have been dedicated to helping me succeed...they are great and always there for me."

\section{Discussion}

The purpose of this study is to understand Black college athletes' perceptions of academic success and how social support contributes to their academic success at predominantly White institutions of higher education (PWIHE). As presented, the NCAA's current definition is specific and clearly reflects cognitive variables as measurements for academic success. However, the findings revealed that seven of the nine participants in this study define academic success as noncognitive variables. This information, thus, becomes significant when understanding how social support contributes to their academic successes. According to House (1981) social support consist of four distinct, yet interconnected functions such as appraisal support, emotional support, informational support, and instrumental support. Ideally, college students should receive all four functions of support, and this is especially the case for marginalized populations (e.g., race, first generation college students; Dennis, Phinney, \& Chuateco, 2005).

Employing critical race theory (CRT) as a theoretical framework provided an opportunity to critically analyze the nine Black college athletes' perceptions and experiences regarding academics and social supports. Critical race theory addresses the significance of race and racism within the educational context and seeks to "transform those structural and cultural aspects of education that maintain subordinate and dominant racial positions in and out of the classroom" (Solórzano \& Yosso, 2002, p. 25). Thus, CRT utilizes a set of tenets to explicate how the notion of White supremacy subjugates persons of color (Ladson-Billings, 1998; LadsonBillings \& Tate, 1995; Tate, 1997; Yosso, 2005). For this study one tenet was used to understand the findings, the centrality of experiential knowledge.

According to CRT scholars, the centrality of experiential knowledge acknowledges the voices of persons of color and accepts them as valid (Solórzano \& Yosso, 2002; Yosso, 2005). Our findings related to how participants defined academic success is applicable here and also consistent with past research. For instance, 
when examining the college experiences of student of color, Saenz, Marcoulides, Junn, and Young (1999) found that for students of color that could apply information learned in their classes to their daily life were more likely to be motivated and achieve academically because they found value in the acquired knowledge. We observed similar dynamics here, as, noncognitive aspects such as motivation and applicability were relevant to the athletes' definition of academic success.

Simons and Van Rheenen (2000) state noncognitive variables such as academic motivation, or "personal effort," are indicators of academic success. In addition, the authors present academic self-concept, educational goals, and mental health also as noncognitive variables that serve as indicators of academic success. This rationale is in response to the belief that standardized examinations are culturally and racially biased (Davis, 2007). This notion was substantiated and placed the NCAA's initial eligibility standards under attack (Haworth, 1999; Williams, 1999). Thus, it is suggested that practitioners consider the role of noncognitive variables in determining academic success for Black college athletes. While it is understood that these noncognitive variables are not meaningful for discerning academic success according to the NCAA, they do serve a purpose by contextualizing the college athlete's mindset and desire for having academic success.

Understanding Black college athletes academic motivation, academic selfconcept, educational goals, and mental health can aid practitioners in providing appropriate types of support. Simons and Van Rheenen (2000) also discuss how noncognitive variables such as "social support" and "parents' and peer educational encouragement" serve as predictors for academic success based on cognitive variables (e.g., course grades, GPA). Adopting this notion, scholars have found merit in acknowledging the noncognitive variables to evaluate the academic success among students of color (Comeaux \& Harrison, 2011; Hood, 1992; Hyatt, 2003; Oliver, Rodriguez, \& Mickelson, 1985; Sedlacek \& Adams-Gaston, 1992; Tracey \& Sedlacek, 1987; Young \& Sowa, 1992). The noncognitive variables consist of motivations and attitudes, personal beliefs, and the campus racial climate which have been factors related to Black students academic persistence and "correlated with the ability to recognize and manage discrimination" (Hyatt, 2003, p. 263).

In addition, campus racial climate and racial discrimination remain issues of concern regarding the experiences and academic realities among students of color at PWIHE (Allen, 1992; Hurtado, 1992; Saenz et al., 1999; Sedlacek, 1987). As a result, Comeaux and Harrison (2007) note that Black college athletes:

may choose to spend as little time as possible with White faculty, who comprise approximately $89 \%$ of faculty at predominantly White institutions, and instead interact and bond with mentors and other support systems off campus where they emphasize feelings of encouragement, acceptance and connection. (p. 10)

Therefore, understanding the role social support plays in the academic experiences for these college athletes was of interest.

Again, social support serves as an important factor to aid stress and/or stressful life events. In this study, the Black college athletes provided insight for on-campus social support. Explicating the nature of on-campus support, the athletes' expressed that academic advisers, tutors, peers, and teammates all served as persons of support. 
The support received from these persons consisted of rules and guidance through mandated study hall hours and course selection, tutorial services in their respective courses, and methods and strategies for completing class projects and preparing for course exams. Each of these aspects is important for academic integration (Heath, Skok, \& McLaughlin, 1991; Saenz et al., 1999). Recognizing this assertion, informational support and instrumental support were the most identified functional areas of support (see also Saenz et al., 1999; Tinto, 1975, 1993). Interestingly, the college athletes did not mention faculty or nonathlete peers in their academic course as persons whom provided these two types of support. Other researchers have observed that students of color who interact with faculty also experience better academic integration (Redmond, 1990; Rowser, 1994; Saenz et al., 1999). Similarly, the notion of faculty interaction is also essential to the success of college athletes (Comeaux \& Harrison, 2007, 2011). More specifically, Comeaux and Harrison (2011) proposed an academic model to promote college athletes academic success. Rooted in the work of Tinto's model of student departure (1975, 1993), college athletes' academic integration was an indicator of academic success.

\section{Practical Implications}

While addressing academic reform was beyond the scope of this research study, the findings from this research may be beneficial to persons in positions of power (i.e., academic advisers, policy makers). Thus, the findings revealed the participants' conceptualization of academic support and their perceptions of how received social support affected their academic success. The participants' affinity for a noncognitive conceptualizations of academic success over cognitive ones is of value. This finding was consistent with scholars' assertions of the value of noncognitive variables in determining academic success (Sedlacek, 1996; Sedlacek \& Adams-Gaston, 1992; Tracey \& Sedlacek, 1984). In addition, aspects of the Tinto's (1993) model of student departure may assist practitioners whom supervise, advise, teach, and/ or guide these persons academically. Yet again, academic success is best achieved when students have interactions with faculty and staff as well as social interactions with peers from their classes.

Issues of academic success and notions of social support can be complex. Accordingly, ascertaining Black college athletes' academic experiences, to include how to ensure academic success, is an ongoing topic of interest. As such, efforts to promote academic or athletic success (e.g., academic support best practices, academic reform policies) need be wary. With respect to academic success, diverse cultures and cultural values must be considered. As Cunningham (2012) articulates, that the NCAA should be mindful of how diverse, and marginalized, populations educational experience(s) are impacted when creating policies and that they not create policies and promote practices that "differentially impact certain groups" (p. 58).

\section{References}

Allen, W. (1992). The color of success: African American college student outcomes at predominantly white and historically Black public colleges and universities. Harvard Educational Review, 62(1), 26-44. 
Anderson, A., \& South, D. (2007). The academic experiences of African American collegiate athletes: Implications for policy and practice. In D.D. Brooks \& R.C. Althouse (Eds.), Diversity and social justice in college sports: Sport management and the student-athlete (pp. 77-94). Morgantown, WV: Fitness Information Technology.

Anshel, M. (2001). Qualitative validation of a model for coping with acute stress in sport. Journal of Sport Behavior, 24, 223-246.

Anshel, M., Sutarso, T., \& Jubenville, C. (2009). Racial and gender differences on sources of acute stress and coping style among competitive athletes. The Journal of Social Psychology, 149(2), 159-177. PubMed doi:10.3200/SOCP.149.2.159-178

Babbie, E. (2001). The practice of social research (9th ed.). Belmont, CA: Wadsworth/ Thomson Learning.

Bell, D. (1980). Brown and the interest-convergence dilemma. In D. Bell (Ed.), Shades of Brown: New perspectives on school desegregation (pp. 90-106). New York: Teachers College Press.

Brown v Board of Education, 347 U.S. 483 (1954). Retrieved February 9, 2011 from http:// www.nationalcenter.org/brown.html

Carter, A. (2008). Negotiation identities: Examining African American female collegiate athlete experiences in predominantly white institutions. Unpublished Dissertation, University of Georgia.

Carter, A.R., \& Hart, A. (2010). Perspectives of mentoring: The Black female student-athlete. Sport Management Review, 13, 382-394. doi:10.1016/j.smr.2010.01.003

Carter, A.R., \& Hawkins, B.J. (2011). Coping strategies among African American female collegiate athletes' in the predominantly white institution. In K. Hylton, A. Pilkington, P. Warmington, and S. Housee (Eds.), Atlantic Crossings: International Dialogues in Critical Race Theory (pp. 61-92). Birmingham, United Kingdom: Sociology, Anthropology, Politics (C-SAP), The Higher Education Academy Network.

Cobb, S. (1976). Social support as a moderator of life stress. Psychosomatic Medicine, 38(5), 300-314. PubMed

Cohen, S. (1986). Social skills and the stress-protective role of social support. Journal of Personality and Social Psychology, 50(5), 963-973. PubMed doi:10.1037/00223514.50.5.963

Comeaux, E., \& Harrison, C.K. (2007). Faculty and male student athletes: racial differences in the environmental predictors of academic achievement. Race, Ethnicity and Education, 10(2), 199-214. doi:10.1080/13613320701330726

Comeaux, E., \& Harrison, C.K. (2011). A conceptual model of academic success for studentathletes. Educational Researcher, 40(5), 235-245. doi:10.3102/0013189X11415260

Cunningham, G.B. (2012). Diversity issues in academic reform. Journal of Intercollegiate Sport, 5, 54-59.

Davis, T. (2007). The persistence of unconscious racism in college sport. In D.D. Brooks \& R.C. Althouse (Eds.), Diversity and Social Justice in College Sport: Sport Management and the Student-Athlete (pp. 263-280). Morgantown, WV: Fitness Information Technology.

Delgado, R. (1989). Storytelling for oppositionist and others: A plea for narrative. Michigan Law Review, 87(8), Legal Storytelling, 2411-2441.

Delgado, R. (Ed.). (1995). Critical race theory: The cutting edge. Philadelphia: Temple University Press.

Delgado, R., \& Stefancic, J. (2001). Critical race theory: An introduction. New York: New York University Press.

Dennis, J., Phinney, J.S., \& Chuateco, L.I. (2005). The role of motivation, parental support, and peer support in the academic success of ethnic minority first-generation college students. Journal of College Student Development, 46(3), 223-236. doi:10.1353/ csd.2005.0023

Denzin, N.K. (1978). The Research Act. New York: McGraw-Hill. 
Donnor, J.K. (2005). Towards an interest-convergence in education of African American football student athletes in major college sports. Race, Ethnicity and Education, 8(1), 45-67. doi:10.1080/1361332052000340999

Edwards, H. (1984). The black "dumb jock": An American sports tragedy. The College Board Review, 131, 8-13.

Edwards, H. (1985). Beyond symptoms: Unethical behavior in American collegiate sport and the problem of the color line. Journal of Sport and Social Issues, 9(3), 3-13.

Evans, N.J., Forney, D.S., \& Guido-DiBrito, F. (1998). Student Development in College: Theory, Research, and Practice. San Francisco, CA: Jossey-Bass Inc., Publishers.

Gaston-Gayles, J.L. (2004). Examining academic and athletic motivation among student athletes at a Division I university. Journal of College Student Development, 45(1), 75-83. doi:10.1353/csd.2004.0005

Glaser, B., \& Strauss, A. (1967). The discovery of grounded theory: Strategies for qualitative research. Chicago: Aldine.

Hawkins, B. (2001). New plantation: The internal colonization of black student-athletes. Winterville, GA: Sadiki.

Hawkins, B. (2010). The new plantation: Black athletes, college sports, and predominantly white NCAA institutions. NY: Palgrave Macmillian.

Haworth, K. (1999). Federal judge bars NCAA from using eligibility rule based on test scores. The Chronicle of Higher Education, 45, A46-A47.

Heath, P., Skok, R., \& McLaughlin, T. (1991). A proposed community college student retention model. College Student Journal, 25(3), 506-514.

Hodge, S.R., Harrison, L., Burden, J.W., \& Dixson, A.D. (2008). Brown in Black and Whitethen and now: A question of educating or sporting African American males in America. The American Behavioral Scientist, 51, 928-952. doi:10.1177/0002764207311998

Hood, D. (1992). Academic and noncognitive factors affecting the retention of black men at predominantly white university. The Journal of Negro Education, 61(1), 12-23. doi: $10.2307 / 2295625$

House, J.S. (1981). Work Stress and Social Support. Reading, Mass: Addison-Wesley.

House, J.S. (1987). Social support and social structure. Sociological Forum, 2(1), 135-146. doi:10.1007/BF01107897

House, J.S., Landis, K.R., \& Umberson, D. (1988). Social relationships and health. Science, 241, 540-545. PubMed doi:10.1126/science.3399889

Hurtado, S. (1992). The campus racial climate: contexts for conflict. The Journal of Higher Education, 63(5), 539-569. doi:10.2307/1982093

Hutchinson, S.R. (2004). Survey research. In K. deMarrais \& S.D. Lapan (Eds.), Foundations for Research: Methods of Inquiry in Education and the Social Sciences (pp. 283-302). Mahwah, NJ: Lawrence Erlbaum Associates, Publishers.

Hyatt, R. (2003). Barriers to persistence among African American intercollegiate athletes: a literature review of non-cognitive variables. College Student Journal, 37(2).

Hylton, K. (2005). Race, sport, and leisure: Lessons from critical race theory. Leisure Studies, 24(1), 81-98. doi:10.1080/02614360412331313494

Ladson-Billings, G. (1998). Just what is critical race theory and what's it doing in a nice field like education? International Journal of Qualitative Studies in Education, 11(1), 7-24. doi:10.1080/095183998236863

Ladson-Billings, G., \& Tate, W. (1995). Toward a critical race theory of education. Teachers College Record, 97(1), 47-68.

Lapchick, R., Hoff, B., \& Kaiser, C. (2011, March 3). The 2010 Racial and gender report card: College Sport. The Institute for Diversity and Ethics in Sport, University of Central Florida: Orlando, Florida.

Lincoln, Y.S., \& Guba, E.G. (1985). Naturalistic inquiry. New York: Sage.

Lynn, M., Yosso, T., Solórzano, D., \& Parker, L. (2002). Critical race theory and education: Qualitative research in the new millennium. Qualitative Inquiry, 8(1), 3-6. doi: $10.1177 / 1077800402008001001$ 
NCAA. (2011a). Education and graduate rates. Retrieved December 16, 2011 from http:// fs.ncaa.org/Docs/newmedia/public/rates/index.html

NCAA. (2011b). NCAA grad rates hit all-time high: Single year Graduation Success Rate reaches 82 percent. Retrieved May 6, 2011 from http://www.ncaa.com/news/ncaa/ article/2011-10-25/ncaa-grad-rates-hit-all-time-high

NCAA. (2011c). Remaining eligible: Academics. Retrieved on December 4, 2012 from http:// www.ncaa.org/wps/wcm/connect/public/ncaa/eligibility/remaining+eligible

NCAA. (2012). Academics: Student-athlete eligibility. Retrieved on December 4, 2012 from http://www.ncaa.org/wps/wcm/connect/public/ncaa/academics/resources/ eligibility

Oriard, M. (2012). NCAA academic reform: History, context, and challenges. Journal of Intercollegiate Sport, 5, 4-18.

Parham, W.D. (1993). The intercollegiate athlete: A 1990's profile. The Counseling Psychologist, 21, 411-429.

Pascarella, E.T., \& Terenzini, P.T. (1998). Studying College Students in the 21st Century: Meeting New Challenges. The Review of Higher Education, 21(2), 151-165.

Pascarella, E.T., \& Terenzini, P.T. (2005). How college affects students: Vol. 2. A third decade of research. San Francisco, CA: Jossey-Bass, Inc.

Procidano, M.E., \& Heller, K. (1983). Measures of perceived social support from friends and family: Three validation studies. American Journal of Community Psychology, 11(1), 1-24. PubMed doi:10.1007/BF00898416

Purdy, D., Eitzen, D., \& Hufnagel, R. (1982). Are athletes also students? The educational attainment of college athletes. Social Problems, 29, 439-448. doi:10.2307/800032

Redmond, S. (1990). Mentoring and cultural diversity in academic settings. The American Behavioral Scientist, 34, 188-200. doi:10.1177/0002764290034002007

Rowser, J. (1994). Teacher expectations: the forgotten variable in the retention of African American students. College Student Journal, 28, 82-87.

Saenz, T., Marcoulides, G.A., Junn, E., \& Young, R. (1999). The relationship between college experience and academic performance among minority students. International Journal of Educational Management, 13(4), 199-207. doi:10.1108/09513549910278124

Sailes, G.A. (1993). An investigation of campus typecasts: The myth of black athlete superiority and the dumb jock stereotype. Sociology of Sport Journal, 10, 88-97.

Sailes, G.A. (1998). A comparison of professional sports career aspirations among athletes. In G. Sailes (Ed.), African Americans in Sport (pp. 261-269). Somerset, NJ: Transaction Publishers.

Sarason, I.G., Levine, H.M., Basham, R.B., \& Sarason, B.R. (1983). Assessing social support: The social support questionnaire. Journal of Personality and Social Psychology, 44(1), 127-139. PubMed doi:10.1037/0022-3514.44.1.127

Schlossberg, N.K., Waters, E.B., \& Goodman, J. (1995). Counseling adults in transition: Linking practice with theory (2nd ed.). New York: Springer.

Sedlacek, W. E. (1987). Black students on White campuses: 20 years of research. Journal of College Student Personnel, 28 (6), 484-495.

Sedlacek, W.E. (1996). Employing noncognitive variables in admitting students of color. New Directions for Student Services, 74(Summer), 79-91. doi:10.1002/ss.37119967408

Sedlacek, W.E., \& Adams-Gaston, J. (1992). Predicting the academic success of studentathletes using SAT and noncognitive variables. Journal of Counseling and Development, 70(6), 724-727. doi:10.1002/j.1556-6676.1992.tb02155.x

Simons, H.D., \& Van Rheenen, D. (2000). Noncognitive predictors of student athletes' academic performance. Journal of College Reading and Learning, 30, 167-181.

Singer, J.N. (2005a). Addressing epistemological racism in sport management research. Journal of Sport Management, 19, 464-479.

Singer, J.N. (2005b). Understanding racism through the eyes of African American male student athletes. Race, Ethnicity and Education, 8(4), 365-386. doi:10.1080/13613320500323963 
Singer, J.N. (2009). Preparing African-American male student-athletes for post-secondary education: Implications for educational stakeholders. In H.R. Milner (Ed.), Diversity and Education: Teachers, Teaching, and Teacher Education (pp. 31-50). Springfield, IL: Charles C. Thomas Publisher, LTD.

Solorzano, D.G., \& Yosso, T.J. (2002). Critical race methodology: Counter-storytelling as an analytical framework for education research. Qualitative Inquiry, 8(1), 23-44.

Steele, C.M., \& Aronson, J. (1995). Stereotype threat and the intellectual test performance of African Americans. Journal of Personality and Social Psychology, 69(5), 797-811. PubMed doi:10.1037/0022-3514.69.5.797

Steele, C.M., Spencer, S.J., \& Aronson, J. (2002). In M. Zanna (Ed.), Advances in experimental social psychology: Vol. 34. Contending with group image: The psychology of stereotype and social identity threat (pp. 379-440). New York, NY: Academic Press.

Tate, W. (1997). Critical race theory and education: History, theory, and implications. Review of Research in Education, 22, 195-247. doi:10.3102/0091732X022001195

Thoits, P.A. (1986). Social support as coping assistance. Journal of Consulting and Clinical Psychology, 54(4), 416-423. PubMed doi:10.1037/0022-006X.54.4.416

Thoits, P.A. (1995). Stress, coping, and social support processes: Where are we? What next? Journal of Health and Social Behavior, 35, 53-79. PubMed doi:10.2307/2626957

Tinto, V. (1975). Dropout from higher education: A theoretical synthesis of recent research. Review of Educational Research, 45(1), 89-125. doi:10.3102/00346543045001089

Tinto, V. (1993). Leaving college: Rethinking the causes and cures of student attrition (2nd ed.). Chicago: The University of Chicago Press.

Tracey, T. J., \& Sedlacek, W. E. (1984). Noncognitive variables in predicting academic success by race. Measurement and Evaluation in Guidance, 16, 171-178.

Tracey, T., \& Sedlacek, W.E. (1987). A comparison of white and black student academic success using non-cognitive variables: A LISREL Analysis. Research in Higher Education, 27(4), 333-348. doi:10.1007/BF00991662

Williams, D. (1999). Changing the rules of the game. Newsweek, 133, 12.

Young, B.D., \& Sowa, C.J. (1992). Predictors of academic success for Black student athletes. Journal of College Student Development, 33(4), 318-324.

Yosso, T. (2005). Whose culture has capital? A critical race theory discussion of community cultural wealth. Race, Ethnicity and Education, 8(1), 69-91. doi:10.1080/1361332052000341006

Vaux, A. (1988). Social support: Theory, research, and intervention. New York, NY: Praeger Publishers. 